\title{
sciendo
}

\section{Setting up a new business - evidence from a business administration faculty}

\author{
Tatiana SEGAL \\ The Bucharest University of Economic Studies, Bucharest, Romania
}

PICBE |

\begin{abstract}
In the last decades, entrepreneurship in all of its complexity, as a basis for sustainable development, has become a major concern for a variety of socio-economic agents: legislative systems, production systems represented by entrepreneurs from all economic sectors, and education and research systems. As a result, numerous fields of studies which aim to develop an entrepreneurial spirit among youth and to prepare students for entrepreneurship have been introduced in the educational curricula starting with high school. One of the missions of the Faculty of Business Administration in foreign languages (FABIZ) from the Bucharest University of Economic Studies is to ensure that students gain the competencies and abilities necessary for being able to open a business and become interested in a career as entrepreneurs. However, discussions with the students from FABIZ showed that only a small percentage of students are planning or have already become entrepreneurs (approximately 5\% which, for some researchers such as Fayolle and Filion (2016) is considered an optimal figure). This study aims to explore the degree to which FABIZ students, with a focus on the French section, are entrepreneurs or, at least, are interested to become entrepreneurs in the near future and to analyse their fields of interests, hopes and fears, i.e. their perception of their own career.
\end{abstract}

Keywords: business, entrepreneurship, entrepreneur, market, job, profession.

\section{Introduction}

The mission adopted by the Faculty of Business Administration in foreign languages from the Bucharest University of Economic Studies is to provide students with the knowledge and skills necessary for managing a business including their own business. In order to achieve this objective, based on the knowledge accumulated in highschool, the academic program comprises a series of subjects, practical activities performed during class hours, and a variety of extracurricular activities which allow students to understand the steps necessary for establishing a business, the complexity of this activity as well as the characteristics, abilities and qualities that they need to develop in order to be able to successfully handle the role of entrepreneur and to enjoy market success.

In this regard, that of becoming an entrepreneur, there are a series of issues. First, a point which was already raised by Segal and Hadad (2017), consists in the fact that in the Romanian Classification of Occupations (COR 2018), there is no mention of the activity of the entrepreneur as defined by Schumpeter (1911), i.e. an activity pursued by an individual who establish a new business or take ownership of an already existent business in order to restart its activities and develop it. There is nonetheless a special code for "entrepreneur in the social economy" (Code 112032) in the primary group 1 of occupations which also includes members of legislative body and of the executive, high dignitaries from the public administration for which there is no specification of a level of required education.

Another issue, also external to the education system, is that of the fact that there are no statistics available regarding the financial situation of SMEs. The White Book of SMEs 
from 2018 published by the National Council of Small and Medium Enterprises from Romania (CNIPMMR 2018) mentions that the difficulties with which SMEs are confronted include: bureaucracy (47.41\%), human resources issues (45.97\%), high fiscality (40.97\%), inflation (40.25\%), as well as unfair competition (40.97\%), that only $0.72 \%$ of the projects for structural fuds were accepted, and that most entrepreneurs (81.75\%) have no intention of accessing structural funds, while $73.88 \%$ of SMEs prefer self-financing. Moreover, Romanian entrepreneurs consider that the greatest obstacles for accessing grants are represented by excessive bureaucracy and the instability of regulations and documentations required $(55.10 \%)$. The same document evidences the fact that the number of organizations which have suspended their activities in the first six months of 2018 was higher with $26.6 \%$ than that from 2017, i.e. from 7597 to 9681 . However, the study does not mention is the suspension is temporary or permanent, and, more to the point, this fundamental study about SMEs does not make any reference to the number of new SMEs established in 2018.

Besides the problems in the environment from which we mentioned a couples, it is worth mentioning that professors need to address the difficulties with which students who are "forced" to simulate the establishment of a business. In this case we can rather talk about particular situations and a subjective point of view, that of the professor who is observing the phenomenon.

At first sight, considering the fields of activity chosen for the future business, we can oscillate between the assumption that students are lacking in imagination, that they are not interested of becoming entrepreneur, or that their level of knowledge is limited by age and experience because of the lack of variety in the fields chosen: leisure activities (restaurants, cafes, inns), commerce and publicity (various types of stores, including online stores or online publicity), event planning (with a focus on floral arrangements), beauty and fitness (beauty parlor, gym, hair dressing salon), education (kindergarten, after school), and less frequently agriculture (medicinal herbs), and rarely production (artisanal products, tailoring, shoemaking).

\section{Research methodology and results}

If we truly exert ourselves to learn about the way in which students conceive their professional future, then we soon realize that the circumstances are much more complex. On the one hand, there are students determined to become entrepreneurs, most of them making their first steps towards this goal during their studies. The number is apparently low (at most $5 \%$ ), but significant if we agree with the experts who contend that this is the optimal percentage. These students know what they want (they have an idea and they put it into practice accepting the risk of failure), they are encouraged by their entourage (family, friends, colleagues) and they are following the courses of FABIZ exclusively in order to gain theoretical knowledge. On the other hand, there is also a category of students who want to become entrepreneurs, but are afraid to assume the risk because they lack self-confidence, and they do not trust their idea and their qualities. These declare that they want to gain a certain level of experience in a specific field before launching into business. Most of them will climb the organizational ladder very quickly and they will "forget" to establish their own business. There is also a third category, that of undecided students, from which a part might attempt to establish a business as a result of the financial situation or as a result of support from their social circles. The last category of students is comprised of those who ended up 
"by mistake" at this faculty and who only desire to work in someone else's business, including as managers.

The purpose of this study is not only to verify the degree to which the aforementioned opinion matches reality, but also to understand what students think regarding their chances as entrepreneurs.

In order to identify the limitations and the benefits of the option of focusing only in FABIZ students from the French section, we propose the following SWOT analysis with respect to the respondents.

\begin{tabular}{|c|c|}
\hline $\begin{array}{ll}\text { Strengths } \\
- & \text { Homogeneity of interests } \\
- & \text { Similarity in age } \\
- & \text { Homogeneity in education } \\
- & \text { Enthusiastic and energic youth } \\
- & \text { Youth open to novelty and change } \\
- & \text { Youth willing to learn and to try }\end{array}$ & $\begin{array}{l}\text { Weaknesses } \\
\begin{aligned} \text { - } & \text { Lack of experience } \\
\text { - } & \text { Limited horizon due to age and } \\
& \text { experience } \\
\text { - } & \text { Lack of ideas } \\
\text { - } & \text { Fierce competition on all levels } \\
\text { - } & \text { Lack of experience working in teams }\end{aligned}\end{array}$ \\
\hline $\begin{array}{l}\text { Opportunities } \\
\text { - Knowing students better (their } \\
\text { desires and their limitations) } \\
\text { - Improving the curricula } \\
\text { - Improving the teaching methods } \\
\text { - Helping students overcome their } \\
\text { fears and their disadvantages }\end{array}$ & $\begin{array}{l}\text { Threats } \\
\text { - Analysis restricted to a limited group } \\
\text { of students } \\
\text { - } \text { Researcher's subjectivity } \\
\text { - Commodity/ inertia among students } \\
\text { - Lack of interaction between the } \\
\quad \text { professor and the students }\end{array}$ \\
\hline
\end{tabular}

To gather data on the students' opinions regarding entrepreneurship, we distributed a survey among FABIZ students and we obtained 308 valid responses. We proceeded to check the representativeness of the sample of students using the formula:

$$
n_{c}=\frac{\mathrm{n} \times \mathrm{N}}{\mathrm{n}+\mathrm{N}}
$$

Where, $\mathrm{n}_{\mathrm{c}}=$ the correct size of the sample for it to be representative

$\mathrm{N}=$ the size of the population

$\mathrm{n}=$ the number of respondents.

In our case, the population was comprised of 1404 students and the number of valid survey answers was 308 . Thus, the right size for the sample $\left(\mathrm{n}_{\mathrm{c}}\right)$ is:

$$
n_{c}=\frac{308 \times 1404}{308+1404}=252.58
$$


Considering that the total number of valid answers is larger than 252 , then we can conclude that the sample is representative. We also have to state that the figures included in the article reflect the results of the research.

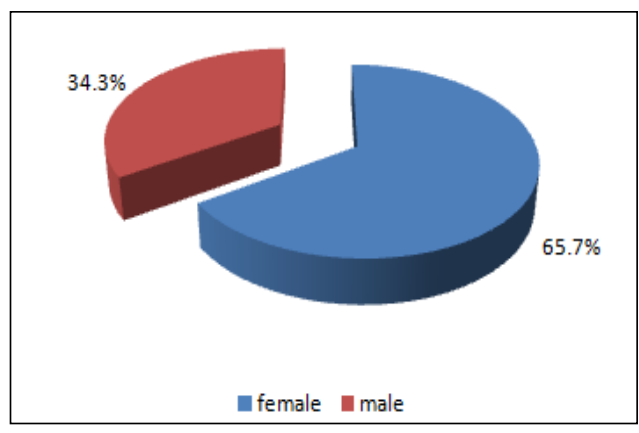

Figure 1 Genre

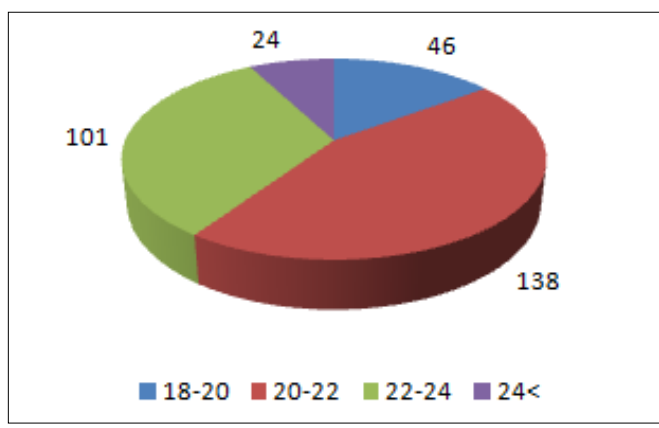

Figure 2 Age

We are being the analysis with a short description of the sample. As we expected, the situation is the following: females predominate (see Figure 1), and most of the students have ages between 20 and 24, comprising both undergraduate and graduate students, with a slight predominance of the undergraduate students (see Figure 2). This is also reflected by Figure 3, where we can see that the number of students from the Bachelor level is almost double the one of students from Master's level.

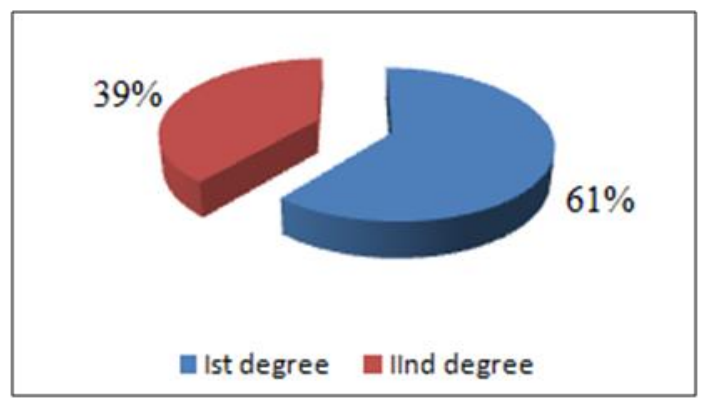

Figure 3 Level of education

If we proceed to the actual study, the first question referred not to the students' intention to become entrepreneurs, but to the timeline in which they think that they will become entrepreneurs, because the lack of desire to establish a business ended the survey. We can see that the majority of students intend to become entrepreneurs in two-year time after finishing their studies. The primary cause for this is their desire to accumulate more experience. In fact, in our opinion, behind this "excuse" there are other reasons such as uncertainty, fear, lack of financial support and others. 


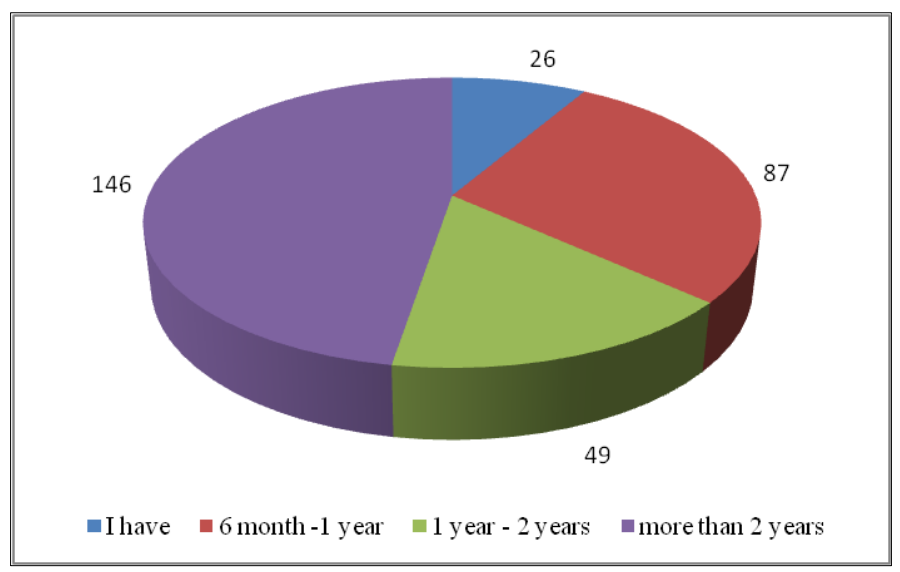

PICBE |

1252

Figure 4 Start up a business

However, there is a large number of entrepreneurs (26 students). This situation is good because, on the one hand, it proves that FABIZ is accomplishing its mission, and, on the other hand, because the percentage of business owners is of $8.44 \%$, which is larger than the standard average of $5 \%$ previously mentioned.

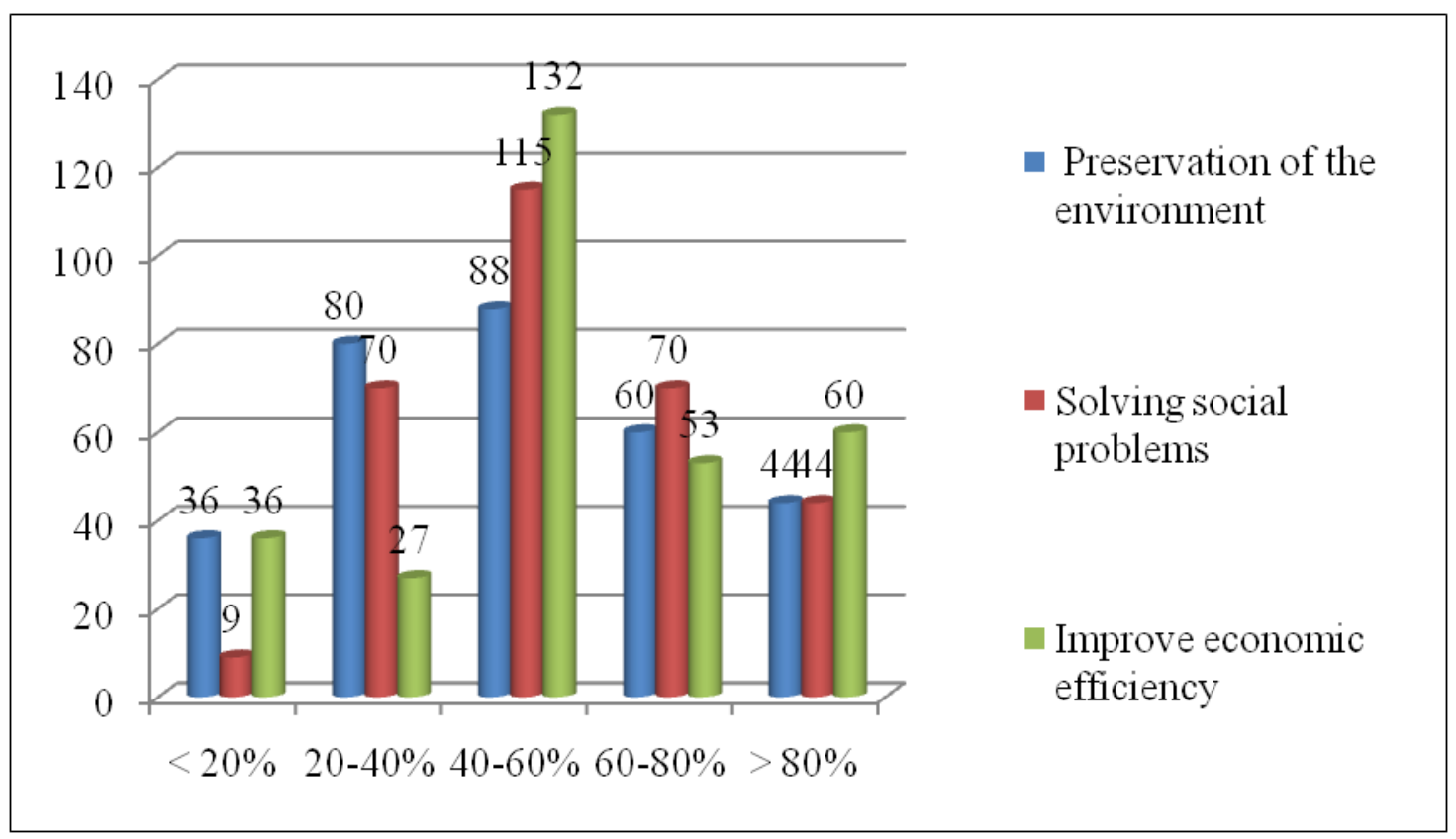

Figure 5 The importance given to the three pillars of sustainable development

As the students manifested their desire to establish a business, we considered it important to verify whether this intention is linked to sustainable development. Thus, the next question took into consideration the three pillars of sustainable development (see Figure 5). We can see that the majority of the students were situated in the interval of average values (40\%-60\%) and that they allocated a greater importance to "actions that ensures the economic progress of the country (improving economic efficiency)". 
Even if these values are sufficiently balanced in the aforementioned interval (a better balance is found for the intervals "60\%-80\%" and "over $80 \%$ "), we consider that a large part of the students is not aware that the three pillars of sustainable development are equally important and interconnected, in the sense that the evolution of one of the pillars creates changes of the same nature (positive or negative) in the other two pillars. Thus, we cannot explain the disparities found in the intervals "under 20\%" and "between 20\%-40\%".

PICBE |

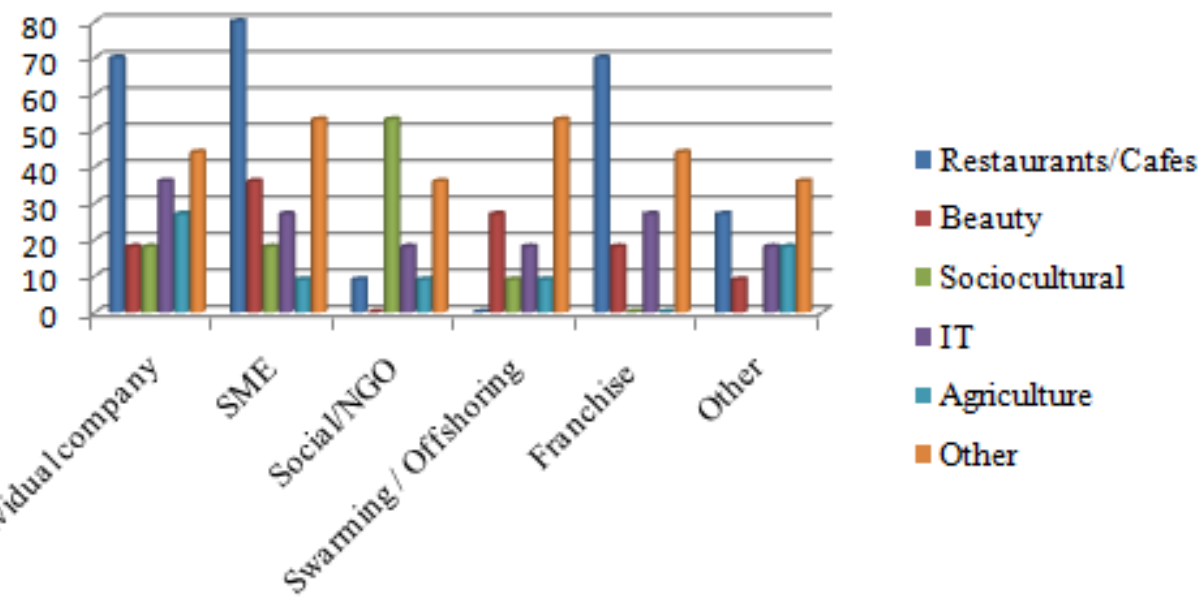

Figure 6 The type of business and the area of interest

To verify the degree to which our opinion regarding to the students' lack of understanding of the system of sustainable development is reliable, and to understand how large the horizon of knowledge of economic life in general is, the next question sought to gather data in the fields in which students want to start their business and the types of enterprises that they intend to establish (see Figure 6).

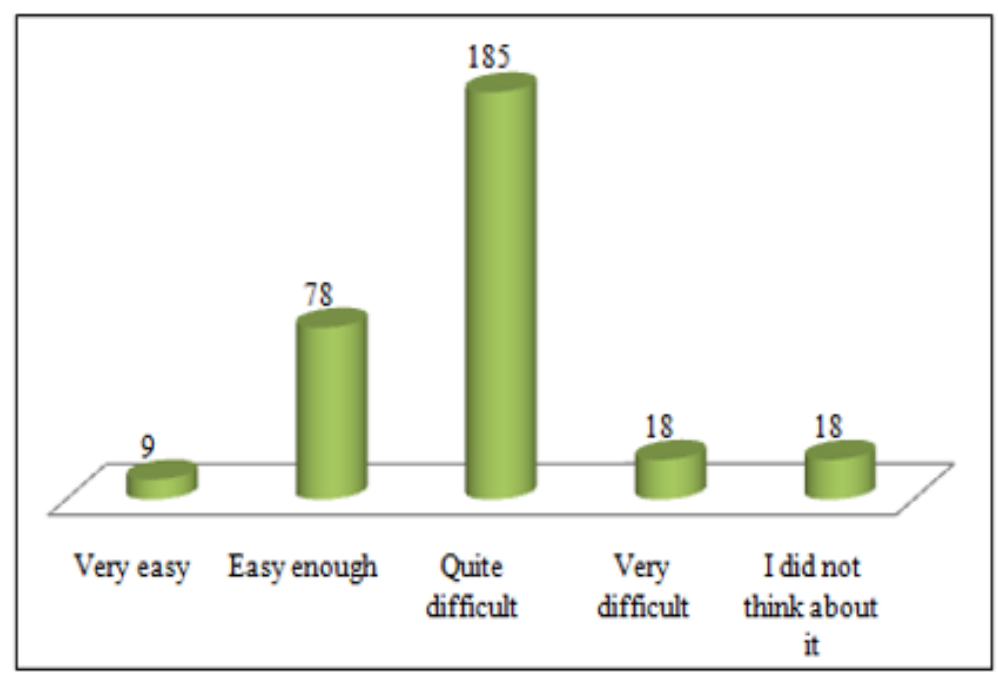

Figure 7 The degree of difficulty of starting a business 
As we expected as a result of experience accumulated in more than ten years of business simulation exercises, the preferred field of activity is food and beverages (restaurant, coffee shop), followed by "others" at a remarkable distance. An additional question revealed the fact that, in this category, students include consulting businesses, private medical clinics (for humans or for pets), flower shops (including floral arrangements for special events).

At this moment, we can conclude that most of the ideas used for business simulation exercises are kept as ideas for actual businesses. This is a proof of perseverance, a quality necessary for becoming a successful entrepreneur. However, if we are to compare the options of business fields with the opinions on sustainable development, we can only draw the conclusion that this concept is not clearly understood.

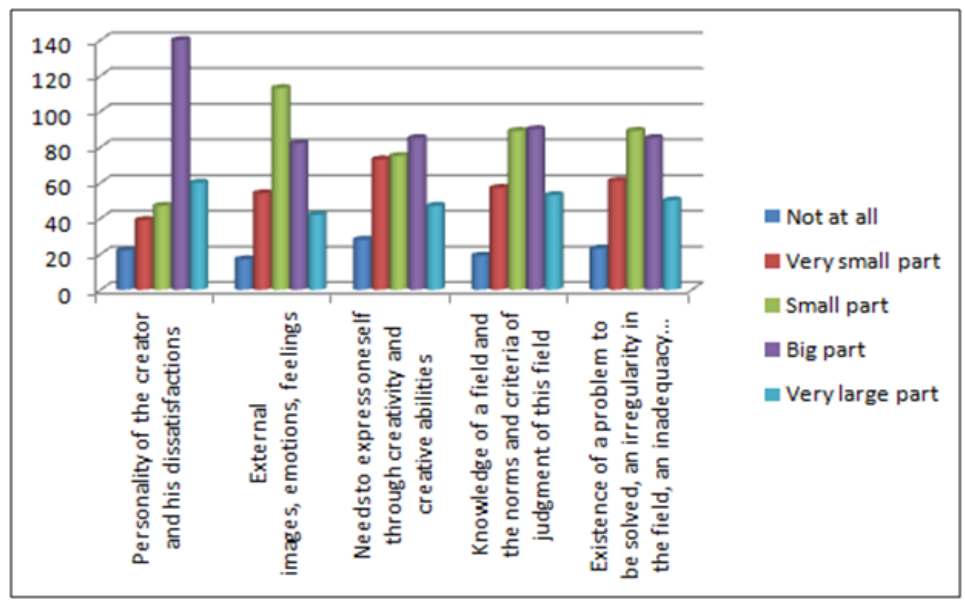

Figure 8 Factors influencing the finding of an original idea

The options are oriented towards businesses, which, apparently, require rather small investments, generate quick financial returns and cater to the needs of young people with an above average standard of living (restaurants and coffee shops).

Regarding the type of business, students prefer SMEs, followed by franchises.

The next step was that of finding out how difficult is in the students' opinions to establish a business. As we can see in Figure 7, most of the respondents consider that it is somewhat difficult to become an entrepreneur. This is probably the reason why they have not started their own business yet. 


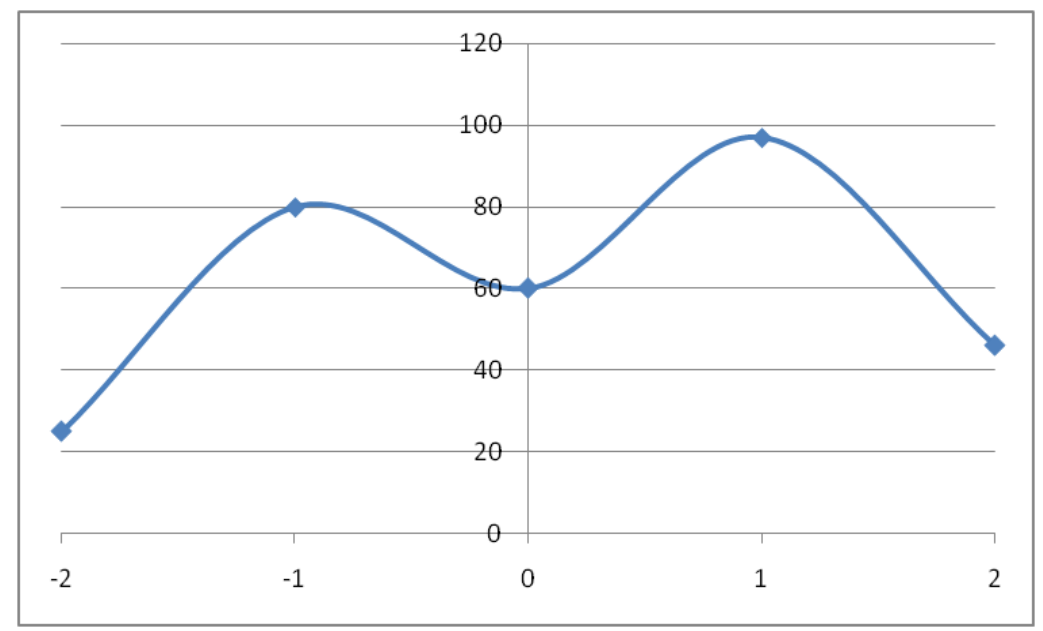

PICBE |

1255

Figure 9 The weight of knowledge about

entrepreneurship

This opinion is based both on objective factors and on subjective ones. Considering that the objective factors are similar to those expressed by early and experienced entrepreneurship, we chose to focus on the subjective factors. One such element is represented by "finding an original idea" which in term can be influenced by other factors. We can see in Figure 8 that the opinion of a large number of theoreticians and practitioners (Fayolle and Filion, 2006; Fayoole, 2008; Papin, 2009) is confirmed by the students: the personality of the creator and his dissatisfactions play for a large part (for 140 students) an essential role in finding a viable business idea. On the second place we find, to a small degree, "external images, emotions and feelings" (113 students). The other factors are well balanced at the level of "to a large extent" and "to a small extent".

Another element of subjective nature which should be taken into consideration is related to "the level of knowledge of entrepreneurship present in the educational curriculum". If we look at the graphic presented in Figure 9, we can observe that the maximal values are found on either side of the central axis at the level of 1 (97 students) and -1 (80 students). This means that the opinions are split almost equally between a reduced level of entrepreneurial knowledge and a high level. If we apply the formula for the Likert scale:

$$
\frac{-2 \times 25+(-1) \times 80+0 \times 60+1 \times 97+2 \times 46}{308}=0,42
$$

We can observe that the result is positive, although closer to 0 than to 1.

Another subjective factor which can be correlated with the level of entrepreneurship knowledge pertains to the characteristics of the students. We took into consideration only six elements: temperament, state of mind, faith (religion), courage, inventiveness and creativity (see Figure 10).

Thee of them, courage, faith and creativity have evolutions which merit further attention. Thus,

a. temperament is at the level of:

$$
\frac{(-2) \times 26+(-1) \times 43+0 \times 55+1 \times 125+2 \times 60}{308}=0,48
$$

b. statem of mind at the level of: 
c. faith at the level of:

$$
\frac{(-2) \times 25+(-1) \times 63+0 \times 75+1 \times 95+2 \times 50}{308}=0,10
$$

$$
\frac{(-2) \times 51+(-1) \times 62+0 \times 99+1 \times 64+2 \times 32}{308}=-0,11
$$

d. courage at the level of:

$$
\frac{(-2) \times 22+(-1) \times 44+0 \times 64+1 \times 89+2 \times 89}{308}=0,58
$$

e. inventiveness at the level of:

$$
\frac{(-2) \times 22+(-1) \times 33+0 \times 67+1 \times 92+2 \times 94}{308}=0,65
$$

f. creativity at the level of:

$$
\frac{(-2) \times 27+(-1) \times 30+0 \times 56+1 \times 84+2 \times 111}{308}=0,72
$$

We can observe that three factors mentioned above have the highest values in ascending order: courage, inventiveness, and creativity. The others register a point of maximum closer or further from the central axis (see for example temperament), the lowest values being registered by state of mind $(0.10)$ and faith $(-0.11)$, which register most of the values in the negative part of the axis.

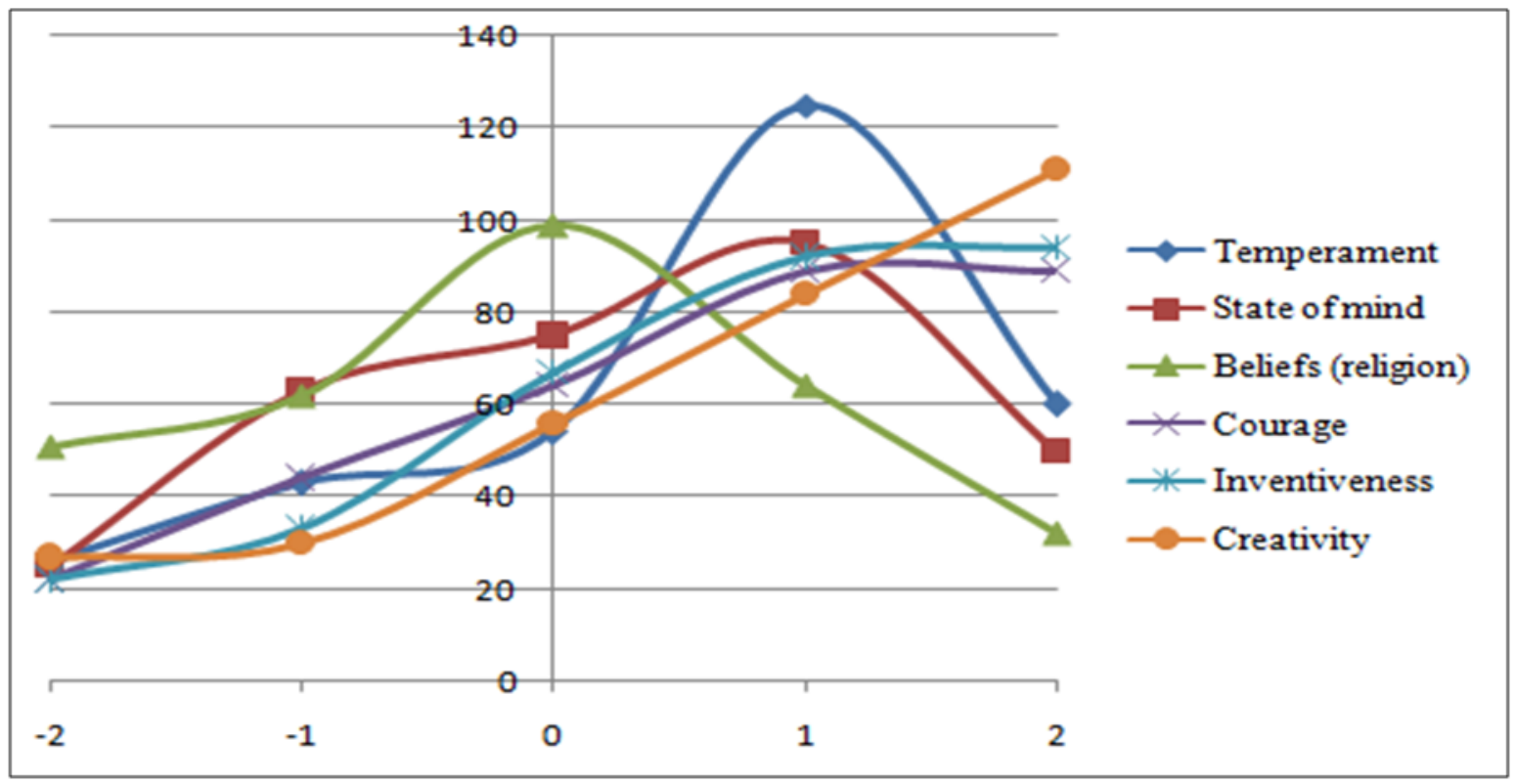

Figure 10 The role of the psychological (personal) characteristics

As a result of the analysis of the last two questions consider that there is a need to change the educational process in order for the students to gain more knowledge regarding entrepreneurship and more confidence in their own abilities. But what exactly needs to be changed? Analysing the answers to the questions referring to the areas in which the students would like to receive support we observe that (see Figure 11):

a. "Need for support with practical aspects" is situated at the level of:

$$
\frac{-2 \times 18+(-1) \times 36+0 \times 62+1 \times 114+2 \times 78}{308}=0,64
$$


b. "Need for support with theoretical aspects" is situated at the level of:

$$
\frac{-2 \times 27+(-1) \times 61+0 \times 132+1 \times 88+2 \times 0}{308}=-0,08
$$

c. "Need for moral support" is situated at the level of:

$$
\frac{-2 \times 36+(-1) \times 79+0 \times 114+1 \times 61+2 \times 18}{308}=-0,17
$$

d. "Need for financial support" is situated at the level of:

$$
\frac{-2 \times 79+(-1) \times 88+0 \times 78+1 \times 27+2 \times 36}{308}=-0,48
$$

e. "Need for advice" is situated at the level of:

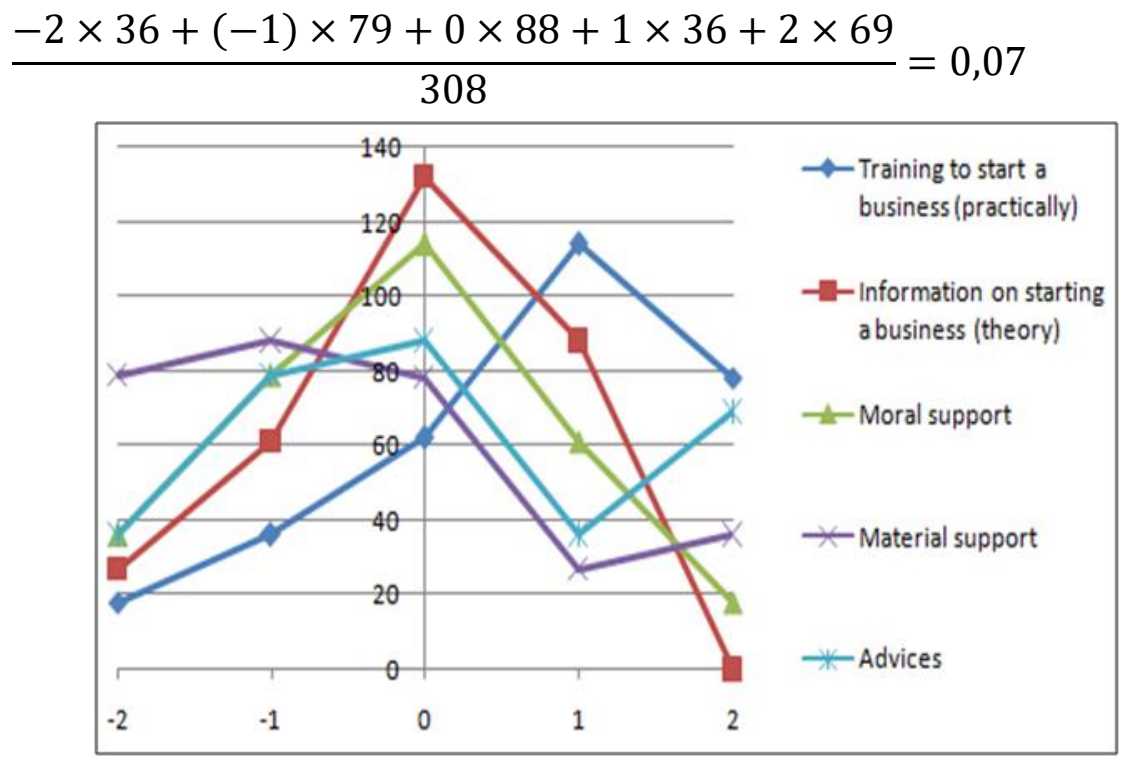

Figure 11 Help expected by students

It can be concluded that there is a need to introduce more practical activities, more projects that stimulate students to open their own business. This is not exactly news because students have asked for more practical activities for a very long time.

After having seen the expectations of the students regarding their preparation for future business owners, we considered it necessary to verify the importance allocated to a series of items related to the job of entrepreneur such as "being your own boss", "taking risks", "putting into practice your ideas" or "having a creative activity", among which we also introduced several items related to daily activities such as "making a career", "deriving satisfaction from work", "having a stable source of income" (the full list of items is available in Figure 12).

For a reliable image of the answers, we performed another analysis of the Likert scale answers and we obtained the following results:

a. being your own boss:

$$
\frac{-2 \times 9+(-1) \times 18+0 \times 44+1 \times 123+2 \times 114}{308}=1,02
$$

b. taking risks:

$$
\frac{-2 \times 9+(-1) \times 18+0 \times 34+1 \times 97+2 \times 150}{308}=1,17
$$


c. putting into practice your ideas:

$$
\frac{-2 \times 9+(-1) \times 18+0 \times 27+1 \times 114+2 \times 140}{308}=1,16
$$

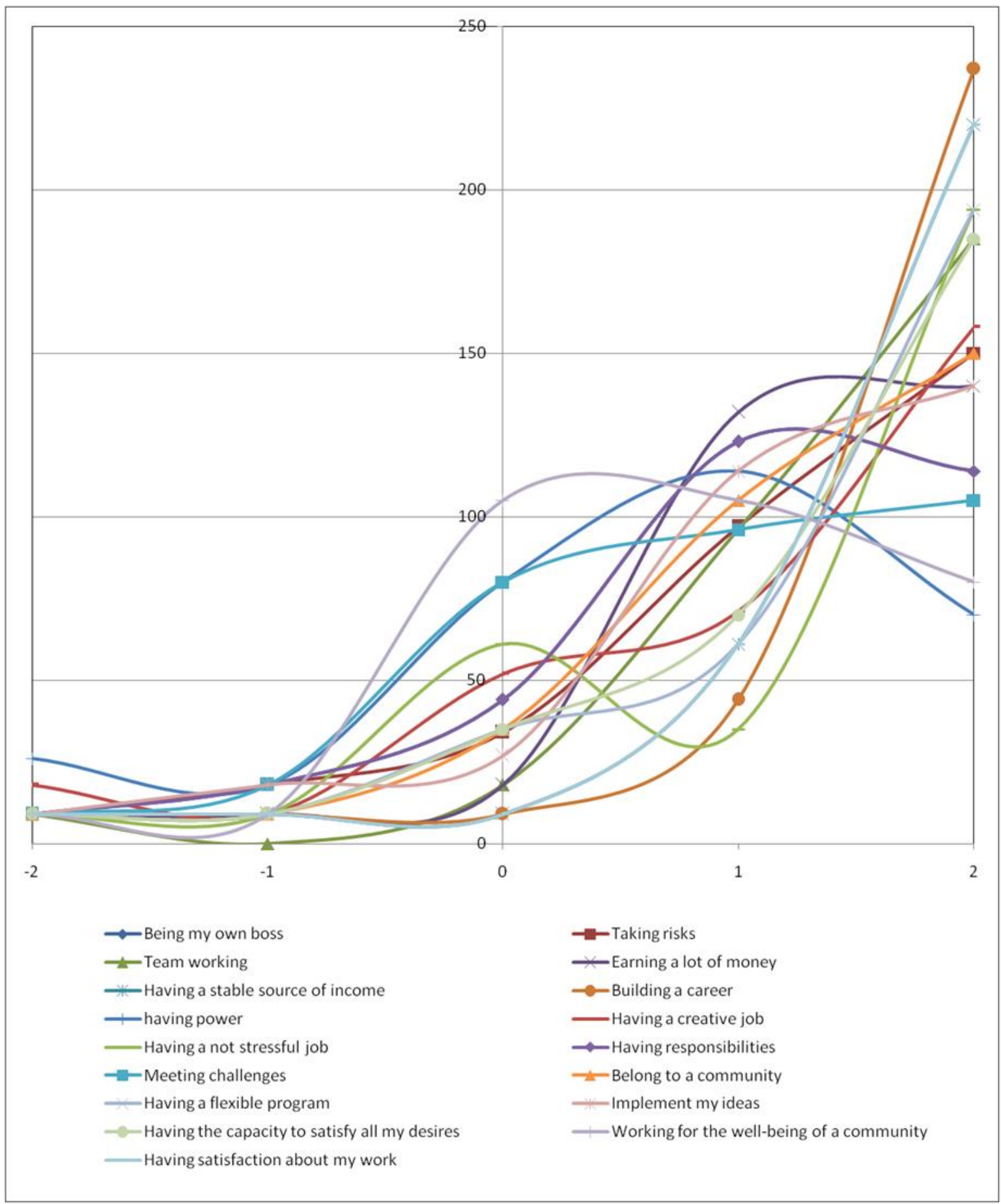

\section{Figure 12 The role of certain items in the future professional life}


d. making a career:

$$
\frac{-2 \times 9+(-1) \times 9+0 \times 9+1 \times 44+2 \times 237}{308}=1,59
$$

e. deriving satisfaction from work:

$$
\frac{-2 \times 9+(-1) \times 9+0 \times 9+1 \times 61+2 \times 220}{308}=1,54
$$

f. having a stable source of income:

$$
\frac{-2 \times 9+(-1) \times 9+0 \times 9+1 \times 61+2 \times 220}{308}=1,54
$$

Surprising or not, the items related to a satisfactory job, a stable income and a successful career received higher scores than others which require people to become involved, to take risks, to have innovative ideas, to manage their resources, even though both categories have scores higher than 1.

Even if, at the moment, the students are interest in the first place to have a career in a multinational company or a large enterprise, but they do not exclude an entrepreneurial career. In light of this we consider that there is a need to verify the degree to which certain orientations related to sustainable development have meaning for them. Thus, the last question referred to the importance allocated to elements directly associated to sustainable development.

Again, the answers received were a bit confusing. If, as some economists argue, the economic pillar is the basis of sustainable development, then the first positions should be occupied by elements such as "promoting a sustained economic growth", "building infrastructure", "ensuring new modes of durable production and consumption". However, for the students, the highest importance is given to "ensuring high quality education". In a way, we can consider that they are right, because an adequate education opens the gates of sustainable development for a country in which the three pillars (economic, social and environmental protection) sustain one another in a harmonious way.

\section{Conclusions}

As conclusions we can state the following:

1. FABIZ students are aware of the positive role played by entrepreneurship and of the advantage that they enjoy as a result of the fact that, at least in theory, they are prepared to become entrepreneurs, but the vast majority prefers to start a career that allows them to accumulate practical knowledge, and capital (financial and relations), and then start their own business.

2. Students manifest a large interest in practical activities to the detriment of theoretical lectures.

3. Sustainable development represents a preoccupation for the students even though, in our opinion, the notion is not clear to them.

4. It is necessary to create an adequate study regarding sustainable development in which the emphasis should be placed on quality, not on quantity.

\section{References}

Balaure, V., Pop, N. A., Teodorescu, N., Cătoiu, I., Adăscăliței, V., Bălan, C., et al. Marketing, ed. Uranus, Bucuresti, 2000

Fayolle, A. et Degeorge, J.-M., « L'opportunité entrepreneuriale au sein d'une organisation : 
processus intuitif et analytique », in Actes de Congrès International Francophone en Entrepreneuriat et PME, Bordeaux, 2010

Fayolle, A., Entrepreneuriat - apprendre à entreprendre, Dunod, Paris, 2008

Fayolle, A., Filion, L.J., Devenir entrepreneur, Pearce Education France, Paris, 2006

Léger-Jarniou, C.,et als, Entrepreneuriat, Dunod, Paris, 2016.

Papin, R., Stratégie pout la création d'entreprise, 13e édition, Dunod, Paris, 2009

PICBE |

Schumpeter, J., Théorie de l'évolution économique (1911), traduction française 1935, in 1260 http://sbisrvntweb.uqac.ca/archivage/13868093t1.pdf

Segal, T, \& Hadad, S, „What it takes to be an entrepreneur in Romania” in Proceedings of the 11 International Conference on Business Excellence, vol. 11, Issue 1 (2017) pp. 464474. ISSN 2558-9652

*** https://www.rubinian.com/cor_1_grupa_majora.php

***http://cnipmmr.ro/2018/07/24/lansarea-editiei-a-xvi-a-a-cartei-albe-a-imm-urilor/

***http://www.ceccarbusinessmagazine.ro/a-xvi-a-editie-a-cartei-albe-a-imm-urilor-dinromania-a3716/

***http://www.ceccarbusinessmagazine.ro/onrc-aproximativ-zece-mii-de-firme-si-aususpendat-activitatea-in -primul-semestru-din-2018-a3784/

***https://www.rubinian.com/cor_6_ocupatia_detalii.php?id=112032 